\title{
Solidarity, SanctionsStpport and Misunderstanding: The European Dimension of the Falklands Crisis ${ }^{\mathrm{i}}$
}

\author{
During the Falklands Crisis Britain made a huge diplomatic effort to win and \\ retain the support of its European Community partners. Largely as a result, the \\ EC implemented a strong series of sanctions against Argentina. The UK also \\ struck up especially close cooperation with both France and Germany. As the \\ crisis developed however, and as force began to be used, maintaining this EC \\ backing became significantly harder. Ireland and Italy were particularly affected \\ by the growing bloodshed. The EC sanctions regime therefore had to flex - \\ exempting both Italy and Ireland from the most stringent measures - but rather \\ contrary to the fears of many did not break. Instead the EC's embargo on \\ Argentina was still functioning when the conflict came to an end. The crisis \\ should therefore be seen as a reminder that well before the 1990s and the creation \\ of the Common Foreign and Security Policy, foreign policy coordination \\ amongst EC member states could be genuinely effective. Despite this success, \\ however, the support received by Britain did not translate into any increase in \\ British public or elite enthusiasm for European integration, despite initial hopes \\ that it might. The article therefore concludes by exploring why there was no \\ European Falklands factor.
}

Keywords: Falklands War; European integration; Britain and Europe; economic sanctions

The significance of the Falklands Crisis for the history of Britain in the 1980s, and more especially for the fortunes of the first Thatcher government is self-evident. ${ }^{\text {ii }}$ Likewise the episode is a major milestone for Argentina, bringing to an end a prolonged and

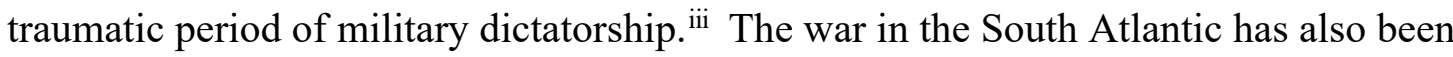
studied as a case study of Anglo-American relations, and there are at least two published accounts of how the episode played out in the United Nations in New York. ${ }^{\text {iv }}$ But the justification for examining this as an episode in European integration history 
and of that important sub-plot of the wider integration story namely Britain's troubled interaction with European Community (EC) and European Union (EU) may be rather less obvious. Certainly it is not something that figures prominently in most existing analyses of either the development of the EC or of Britain's relationship with Brussels. ${ }^{\mathrm{v}}$

At the time, however, a huge diplomatic effort was made by the United Kingdom to win and retain the support of their European partners in the conflict with Argentina. Largely as a result, the crisis saw the remarkably swift imposition of a European economic embargo on Argentina - a show of diplomatic unity and resolve that surprised Europeans, Argentines and outside observers alike. Of particular significance was the intense bilateral interaction between the UK and its two largest European partners, France and West Germany, who also happened to be amongst the major military suppliers to the Argentinian government. Exchanges between London, Paris and Bonn about the situation in the South Atlantic highlighted both the potential benefits and the frustrations of trying to conduct a diplomatic and then military operation while keeping close partners sufficiently informed. Maintaining Community solidarity also became significantly harder as it became clearer that diplomacy alone would not suffice to reverse the Argentinian invasion and that fighting would be necessary. The more pessimistic assessments predicting the complete collapse of EC unity over the issue would prove ill-founded, however, and both economic sanctions and a degree of political and diplomatic backing to Britain was successfully maintained until the end of the conflict. A close examination of the crisis would therefore suggest that foreign policy coordination within the 1980s European Community was rather more effective than has often been assumed in the literature. Despite the resilience of EC solidarity in the dispute, however, the episode failed to deliver the widely anticipated positive transformation of British attitudes towards the European Community. There 
was no 'Falklands Factor' in terms of UK popular or political attitudes towards the EC. $\underline{\text { vi }}$ In addition to analysing the European dimensions of the Falklands War that did exist, therefore, this piece will also seek to answer why the hoped for fillip to British Europeanism ultimately failed to materialise.

\section{'The EC came through for us'}

The initial response of the EC to the Argentinian invasion of the Falkland islands on the morning of 2 April 1982 was a rapid and surprisingly forceful demonstration of what European coordination on foreign policy issues could achieve. The first step was a strongly worded condemnation of the invasion by the foreign ministers of the Ten issued that same evening. ${ }^{\text {vii }}$ This had been drafted in Whitehall, relayed to Brussels where it was discussed by the seven political directors - i.e. the national diplomats responsible for coordinating foreign policy positions amongst the ten member states who happened to be there already on other business, significantly amended at the request of the Irish in particular, and then distributed to European capitals by the Belgian presidency with the instruction that it would be published immediately unless they heard back to the contrary. ${ }^{\text {viii }}$ Despite the fact that Brussels like most other European capitals was rapidly emptying in the run-up to Easter, there was hence no repeat of the embarrassing delay before a collective European prise de position which had occurred when a previous crisis - the Soviet invasion of Afghanistan in late December 1979 - had coincided with a major European holiday season. ${ }^{i x}$ Little wonder that one Community official told the press, with a touch of hyperbole, 'We have done in a day what it normally takes a year to do.' ${ }^{x}$

Strong words were rapidly followed up with strong action. The EC's track record on economic sanctions had not been a distinguished one prior to 1982. Member 
states had disagreed with each other badly on the imposition of sanctions on apartheid South Africa during the 1970s; in 1982 the steps taken against the Soviet Union in retaliation for the imposition of Martial Law in Poland fell far short of what the US had hoped for from its main European allies. ${ }^{x i}$ Nor were the British particularly confident that their European partners would be prepared to put at risk their very substantial trade relations with Argentina. A note from Lord Carrington to the Prime Minister, written the day that he resigned as Foreign Secretary, stressed how much more effective economic pressure would be were it not just exercised by Britain alone, but predicted that the other Community member states 'are unlikely to be willing to go [as] far' as a total embargo of imports. He therefore recommended requesting that they impose an arms embargo, some limited import bans, and restrict export credit facilities. ${ }^{\text {xii }}$ In the event, however, the British quickly discovered that their EC partners were willing to contemplate a total import ban. There was, it is true, some wrangling over whether the steps taken should be national measures, coordinated by the EC using article 224 of the Treaty of Rome, or Community measures enacted via article 113. ${ }^{\text {xiii }}$ States like Denmark, but also initially the French and the British believed that the former mechanism would be more appropriate, given the political nature of the crisis. ${ }^{\text {xiv }}$ Foreign policy coordination was an intergovernmental affair, not something that was the responsibility of the EC per se. ${ }^{\mathrm{xv}}$ But others, notably the Benelux states, were attracted by the more Communautaire and uniform nature of article 113 sanctions, and felt that an economic measure like the imposition of sanctions was a Community matter. And for a country like Italy, where, for reasons that will be discussed further below, sanctions would be especially painful and controversial, there was a strong feeling that so drastic a measure could only be contemplated if carried out multilaterally rather than through national provisions. ${ }^{\mathrm{xvi}}$ It would take a clever compromise suggestion by the 
European Commission, justifying the sanctions under article 224 but implementing them using article 113, to finesse this divide. ${ }^{x v i i}$ Thanks to the Commission's intervention and overnight Italian decision to go along with the consensus that had emerged the previous day, the member state permanent representatives recalled to Brussels in the midst of the holiday season, were able on Saturday 10 April to agree to the most forceful set of sanctions that the EC had ever devised, including a ban on new imports, an arms embargo and restrictions on the granting of export credit insurance. ${ }^{\text {xviii }}$ Agreeing on the duration of these measures took a little bit longer, but by 14 April the British had been able to persuade their partners that the sanctions should last for a month rather than the 15 days initially proposed by the Commission. ${ }^{\text {xix }}$ Implementation would begin on 16 April, a fortnight after the invasion.

Getting to this outcome so rapidly had taken a forceful deployment of British political persuasion, aided and abetted by a helpful Belgian presidency. Sir Julian Bullard, the British political director had been in frequent touch with his counterparts across Europe, and had outlined what support Britain hoped for in meetings in Brussels on both 2 April and 9 April. ${ }^{\mathrm{xx}}$ The UK permanent representation in Brussels (UKREP), the de facto British embassy to the EEC, had been similarly hyperactive: William Nicoll, the deputy permanent representative, set out the British position in the crucial meetings of the permanent representatives committee (COREPER). ${ }^{\mathrm{xxi}}$ Christopher Tugendhat and Ivor Richard, the two British Commissioners had been mobilised, and direct contact had been made with Etienne Davignon and François-Xavier Ortoli, two of the most powerful Commissioners, as well as with the institution's president, Gaston Thorn. ${ }^{x x i i}$ British members of the European Parliament also became involved lobbying for action in support of the UK, especially Lord Plumb, the leader of the Conservatives in Strasbourg. ${ }^{\text {xiii }}$ And the Prime Minister made an appeal to each of the leaders of the 
European Community countries - as well as to the Australians, Canadians, New Zealanders, Japanese and Americans. ${ }^{x x i v}$ Throughout the process, the Belgian government, which held the rotating presidency of the EC Council of Ministers, and as such was responsible for convening and chairing meetings, and setting their agenda, proved highly amenable to British requests, appealed to Community solidarity, and was effective in preventing any significant delays. ${ }^{\mathrm{xxv}}$ And all of the Ten showed a willingness to engage directly with the British appeal for help, however awkwardly timed. Helmut Schmidt, the German Chancellor for instance, abandoned his own Easter break to return to Bonn to chair a cabinet meeting on 7 April that forcefully proclaimed the Federal Republic's condemnation of the Argentine invasion and its support for 'a close ally... and fellow member of the Community'. ${ }^{x x v i}$ It was, as Thatcher herself acknowledged in a message of thanks sent to her European counterparts after the sanctions had been approved, 'an impressive example of Community cooperation at its best'. ${ }^{x x v i i}$

EC backing was likely to have significant effects, furthermore. In the short term it provided a highly welcome boost to British morale. Thatcher's 12 April outburst, at the start of the crucial_first-meeting with Alexander Haig, the US Secretary of State, who had taken it upon himself to lead the mediation effort to resolve the crisis, was revealing: "The EC came through for us. The meeting "turned up trumps". We are pleased. ${ }^{\text {xxviii }}$ The contrast with the studiously neutral public stance initially adopted by the Reagan administration was particularly striking. ${ }^{\text {xxix }}$ Prompt EC support for the UK also facilitated the parallel British effort to secure international backing at the United Nations. The Irish Permanent Representative to the UN, for example, recalls how much easier it became to speak and vote in favour of the crucial Security Council Resolution (SCR) 502, calling for an immediate Argentinian withdrawal, in the light of the strong 
EC statement of 2 April. ${ }^{\mathrm{xxx}}$ By contrast Spain, which was not yet a member state, and as such was not bound by the EC position, abstained over SCR 502. ${ }^{\mathrm{xxxi}}$ France, meanwhile, used its considerable influence in sub-Saharan Africa to help win over Zaire and Togo, both of whom, like Ireland, were temporary members of the Security Council in 1982, and whose votes were therefore crucial to UK efforts in New York. ${ }^{\text {xxxii }}$ The Americans were also impressed: George Vest, the US ambassador to the EC, told a senior British diplomat that he was 'very struck by the complete solidarity of our European partners in the Ten. ${ }^{\text {xxxii }}$ And the forcefulness of the EC response had the potential to heighten Argentina's sense of isolation. In a conversation with the German ambassador to Buenos Aires on April 3, passed on in confidence to British diplomats, the Argentinian leader, General Leopoldo Galtieri, expressed scepticism about the likely success of US mediation efforts and added that he felt that there was more sympathy in Europe than in Washington for the Argentine position. ${ }^{\text {xxiv }}$ The EC decision a few days later to press ahead with forceful economic sanctions must hence have come as something of a shock to the Argentinian Junta. The volume and value of trade links between Western Europe and Argentina meant, moreover, that EC economic sanctions had the medium term potential to do real harm to the already fragile Argentinian economy. In the late 1970s and early 1980s between a quarter and a third of Argentina's exports were sold to the EC, mainly to Italy, Germany and the Netherlands. ${ }^{\mathrm{xxx}}$ Britain's other allies to adopt economic sanctions against Argentina, notably Canada, Australia, New Zealand and Hong Kong, accounted, by contrast, for less than $1 \%$ of Argentinian exports. ${ }^{x x x v i}$ Depriving Argentina of access to European markets was an economic step of real significance in other words. And the EC arms embargo was also likely to hurt, given that Germany, France and Italy were the country's principal suppliers. ${ }^{\text {xxxvii }}$ CIA analysts were almost certainly correct in their 
assessment that the Argentinian economy was strong enough to resist the immediate impact of the EC measures. ${ }^{\text {xxxvii }}$ But the sanctions imposed were fierce enough to have genuine medium term repercussions, and, perhaps more importantly, an instant psychological effect. British satisfaction at their success in Brussels was comprehensible. As Thatcher put it to the House of Commons on 14 April:

[The imposition of sanctions] is a very important step, unprecedented in its scope and the rapidity of the decision. Last year about a quarter of all Argentina's exports went to the European Community. The effect on Argentina's economy of this measure will therefore be considerable and cannot be without influence on her leaders in the present crisis. I should like warmly to thank our European partners for rallying to our support. It was an effective demonstration of Community solidarity. ${ }^{\mathrm{xxix}}$

\section{Some partners are more equal than others: the French and German role}

British diplomacy was particularly focused during the Falklands crisis on the two biggest EC member states, France and Germany. To some extent of course this was no more than business as usual. UK governments have always tended to prioritise relations with the other big countries in Europe, and have been prone to be unduly dismissive of the role of their smaller partners. ${ }^{\mathrm{xl}}$ A similar concentration on Paris and Bonn was to occur, for instance, a couple of years later, in the climatic moments of the row over the British contribution to the Community budget. ${ }^{x l i}$ But in the case of the Falklands War, the extra levels of UK attention lavished on France and Germany derived some degree of justification from the two countries' roles as the main arms suppliers to the Argentinian regime. Close dialogue with both Paris and Bonn thus became imperative, both to find out more about Argentina's existing military capabilities, and to ensure that no further weapons reached the country, conceivably via third parties, either during or immediately after the conflict. 
Talking to the French was made easier by the fact that France was the only other EC member with a comparable range of far-flung and potentially vulnerable territories left over from its imperial heyday, as well as the only other EC member to have recently used military force outside of Europe. ${ }^{\text {xli }}$ This made it much easier for French opinion at both elite and popular level to relate to Britain's predicament, and much readier to accept that force might well have to be used in order to regain possession of the Falklands. Such sympathy and understanding began at the very top. ${ }^{\text {xliii }}$ François Mitterrand was one of the first international leaders to call the Prime Minister to express his strong support, and his willingness to do all that he could to help. ${ }^{\text {xliv }}$ Thatcher sounded genuinely moved, declaring towards the end of their conversation that 'we all have need of friends at difficult times, and that's when we particularly appreciate them.' ${ }^{\text {xlv }}$ She also sent the French President a conspicuously warm message of thanks the following day. ${ }^{x l v i}$ And this personal rapport on the issue persisted throughout the crisis, all the more noticeable for the way in which solidarity over the South Atlantic co-existed with strong Anglo-French disagreement over questions such as Britain's budgetary contribution to the EC. ${ }^{\text {xlvii }}$

France was also able to supply the British with very practical assistance. Help in securing support from some sub-Saharan African countries in the UN was noted earlier. Similarly both Mitterrand and the French Foreign Minister Claude Cheysson lobbied for greater international backing for Britain: in late April Thatcher again wrote to the French President to thank him for his and Cheysson's efforts to persuade the Japanese to be more vigorous in their support. ${ }^{x l v i i}$ Equally valuable was advice for the British armed forces about the French-supplied weapons systems that the British might find themselves up against. In early April, the British defence attaché in Paris was invited by Charles Hernu, the French Minister of Defence, to pose whatever questions 
he liked to civil servants about military materiel sold to Argentina. ${ }^{\text {lix }}$ The answers received included details about the exact number of Exocet missiles sold. ${ }^{1}$ British Harrier pilots were provided with special training for combat against the Mirage fighters that they were likely to encounter. ${ }^{\text {li }}$ And the French were also prepared to delay the delivery of new weapons, notably Exocets and the Super Étendard aircraft they were launched from, to Peru, in response to UK fears that the Peruvians would pass them on to Argentina. lii The epithet 'our greatest ally' applied by Defence Secretary John Nott to Mitterrand and the French was hence well deserved, despite the somewhat murky role played by Dassault, the makers of the Exocet missiles, who would appear to have supplied technical assistance to the Argentinians during the conflict itself. ${ }^{\text {liii }}$

Germany's position was somewhat more ambivalent throughout. In part this reflected the rather scratchy relationship between Thatcher and Schmidt. The two leaders could and did agree at times, including over the Falklands, but their rapport had been badly damaged by the long-running dispute over Britain's contribution to the EC budget and by the Chancellor's growing disillusionment with the realities of British involvement in the integration process. ${ }^{\text {liv }}$ Also problematic was the way in which, for entirely understandable reasons, both the German political class and the wider population were acutely uncomfortable with military action. ${ }^{\text {lv }}$ Such distaste for bloodshed was only accentuated in a situation in which the potential confrontation centred on the fate of, as one columnist in Die Zeit put it, 'a couple of thousand shepherds'. ${ }^{\text {vi }}$ The Bonn government, with its strongly Cold War tinted world-view and its close ties with Washington, was also more receptive than many other European countries to US anxieties about conflict with Argentina opening the door to greater Soviet penetration of Latin America. ${ }^{\text {lii }}$ Even more fundamentally, the Federal Republic in 1982 remained a highly cautious international player, reluctant to throw its weight 
around, anxious of offending potential partners and clients, and hesitant about standing out from the crowd in terms of its foreign policy positions. The eagerness of German diplomats, in their early exchanges with British counterparts about the Falklands and about possible international and Community responses, to establish what their counterparts elsewhere had said and what line other countries were likely to take, was most revealing in this regard. .viii $^{\text {. }}$

Despite this, however, German support, especially early on, was actually surprisingly robust. Hans-Dietrich Genscher, the Foreign Minister, was particularly outspoken on the need to back the British. This became clear from Genscher and President Carsten's state visit to Brazil in the first week of April, where the German representatives used their entirely coincidental presence in Latin America strongly to condemn the illegal Argentinian invasion - a gesture that prompted the British ambassador who was a guest at the state banquet in Brasilia to comment 'the Germans have done us proud here'. lix It was confirmed in a long conversation between Genscher and the British Ambassador in Bonn, Sir Jock Taylor, in mid-April, in the course of which the foreign minister underlined how strongly he felt that his country should stand behind a close ally and Community partner, irrespective of the substantial damage that economic sanctions might do to the FRG's export-orientated economy. ${ }^{\mathrm{lx}}$ And Genscher's backing was at its most valuable in early May when the mood at an informal meeting of European foreign ministers which had started in hazardous fashion for the British with the Irish foreign minister, Gerald Collins, explaining how his country no longer felt able to support sanctions following the sinking of the General Belgrano, was turned around by a forceful statement from the German foreign minister that 'an ally is an ally, a friend is a friend'. $x i$ 
Like the French, moreover, the Germans proved willing to cooperate with the UK government to delay the delivery of armaments that might be used against British forces. In the German case, London's anxieties centred on the likely delivery schedule of four frigates that were being built in Hamburg by Blohm und Voss for the Argentinian navy. ${ }^{\text {lii }}$ This was not something that was likely to happen in the spring or early summer, as the boats in question had yet to undergo their sea-trials, but the British government would go on pressing the Germans to postpone the delivery until late 1982. Despite mounting anxieties that the lucrative contract would fall through altogether were the sale postponed for too long, potentially leaving the Federal authorities liable for the firm's substantial losses, the German government largely went along with Britain's requests. ${ }^{\text {liii }}$

In return for such cooperation, the British made an effort to provide their two most important European allies with rather more information about how their diplomatic and military strategy was evolving than was made available to other European countries. The special French role seems to have been acknowledged from the outset, Bullard agreeing with the Emmanuel de Margerie, the French ambassador in London, at the end of the first briefing of EC ambassadors on the crisis that 'a direct channel of communication on this subject' should be set up with the French embassy. ${ }^{\text {lxiv }}$ Taylor had to lobby rather harder for similar privileges to be accorded to the Germans too. Several of his early reports underlined how vital it would be to make the Federal Republic feel as if it was being consulted with and informed as much as was possible, but his initial suggestion that special briefings be organised for the German ambassador in London was rebuffed by the FCO. ${ }^{\mathrm{lx}}$ The importance of keeping Bonn onside was gradually acknowledged, however. By late April, the Ministry of Defence had been asked to organise regular briefings for the German Defence Attaché - a move 
subsequently extended to other Community member states also - and the German ambassador was being encouraged to visit Bullard often so as to be kept up to date. ${ }^{\text {lxvi }}$ Even more strikingly, in early June, the State Secretary at the German Foreign Ministry, Berndt von Staden, and his French counterpart, Francis Gutmann, travelled to London for a lengthy discussion of the Falklands crisis with the Permanent Undersecretary of the FCO Sir Antony Acland and his predecessor Sir Michael Palliser Sir Antony Acland, a privilege that all of those involved were keen to keep secret for fear of provoking resentment amongst those European countries not invited. ${ }^{1 x v i i}$ And a similar pattern of unusually close consultation was evident at senior political level too. Francis Pym $_{2}$ Carrington's replacement as Foreign Secretary, thus went out of his way to schedule an additional bilateral meeting with Genscher in early May, as well as a fourway exchange with Genscher, Cheysson and Emilio Colombo, the Italian foreign minister, on the margins of the NATO ministerial gathering in Luxembourg. ${ }^{\text {lxviii }}$ Thatcher meanwhile had two telephone conversations with Schmidt and one with Mitterrand during the Falklands crisis, met the French President in person on 17 May, and organised a bilateral with the German Chancellor while both leaders were in Versailles for the G7 summit. ${ }^{\text {xix }}$ Needless to say such exchanges were not exclusively about the Falklands, and also dealt with internal Community matters and much else besides. But they did serve to emphasise the degree to which the British government was prepared to single out the French and Germans for much more extensive consultation, thereby highlighting how crucial their support was deemed to be.

\section{A fragile consensus}

As the crisis wore on, and as it became increasingly clear that the dispute would be resolved through force rather than diplomatic pressure, EC support for the British did 
become rather more fragile. Three member states in particular had growing difficulties with the idea of prolonging the month-long economic sanctions against Argentina. Of these, the least problematic from a British perspective, was Denmark, whose objections centred not on the principle of supporting the UK's effort and maintaining pressure on Argentina, but much more narrowly on the specific legal mechanism chosen to do so. ${ }^{\text {lxx }}$ The Danes had never been happy with the use of article 113 of the Treaty of Rome to impose Community sanctions on Argentina, and had gone along reluctantly with the hybrid article 113/224 solution proposed by the Commission in April. By early May, as discussions began about renewing the sanctions, they were thus determined not to allow a second use of article 113. This attitude, grounded in a profound dislike of the Community involving itself in political matters that the Danes believed were best handled intergovernmentally, proved a bureaucratic headache for London, the European Commission and the Belgian presidency. ${ }^{\text {lxxi }}$ It also raised awkward questions of timing, since passing national laws to prolong the sanctions would be hard to coordinate with the expiry of Community measures. But it did little seriously to undermine the united European front vis-à-vis Argentina. Denmark after all had no intention of resuming trade with Argentina or denouncing the Community solidarity being shown to the UK. It simply had a deep-seated but technical objection to the manner in which the policy had originally been carried out. Italian and Irish concerns by contrast were much more fundamental.

In the Italian case, the root difficulty lay in the fact that as much as half of the Argentinian population was of Italian heritage, often quite recent. As the Prime Minister Giovanni Spadolini commented to Schmidt, when the two leaders met in Hamburg on May 10, this included Galtieri himself. ${ }^{\text {lxxii }}$ Italian public opinion was hence inevitably highly sensitive, especially from early May onwards once blood began 
to be shed. ${ }^{\text {lxiii }}$ Close kinship ties had also encouraged extremely close economic bonds between Italy and Argentina. In addition to being a major importer of Argentinian produce and one of the main exporters to the country, Italy was also the largest European investor in Argentina with several leading Italian firms operating significant Argentinian subsidiaries. ${ }^{\text {lxxiv }}$ In consequence, economic sanctions were especially difficult for Italy to bear - and even more so once Argentina began to threaten to debar European firms from public tenders because of the sanctions regime. ${ }^{\operatorname{lxv}}$ The deep rooted cultural and economic links, also gave Argentina a direct entrée into Italian domestic politics. ${ }^{\text {lxxvi }}$ A number of Argentinian delegations visited Italy during the crisis months, lobbying for Rome to take a more balanced position between Britain and Argentina and playing upon the closeness of pre-existing ties between, for instance, Italian Christian Democrats and their counterparts in Buenos Aires. ${ }^{\text {lxxvii }}$ Even more basically, multiple thousand dual-nationals, living in Argentina, might soon be entitled to vote in Italian elections. ${ }^{\text {lxxviii }}$ All this helps explain why the ambitious, but unscrupulous leader of the Italian socialist party, the PSI, Bettino Craxi decided to use the issue to put immense pressure on the four other parties in the governing coalition to withdraw Italian support for the renewal of sanctions, and why ultimately neither Colombo from the Christian Democrats nor Spadolini from the much smaller

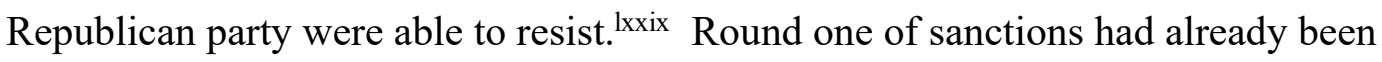
difficult for the Italians to accept, but had been possible to sign up for, partly because hopes were still high in early April that the dispute might be resolved without shots being fired, and partly because those opposed to sanctions had not yet had much time to organise. By May, when the question of renewal needed to be faced, neither of these mitigating factors still applied. 
Ireland too had profound misgivings about the use of force. ${ }^{\operatorname{lxx}}$ As with the Italians, warning signs were there from the outset, despite the country's willingness to vote for SCR502 and accept the first round of Community sanctions. ${ }^{\text {lxxxi }}$ The Taoiseach, Charles Haughey, had tried somewhat unconvincingly in the weeks that followed to suggest that the UN vote had not been fully in line with his preferences. ${ }^{\text {lxxxii }}$ This suggested an early disinclination to be seen to be too supportive of Britain. lxxxiii But the real turning point in the Irish position would occur in early May, following the sinking of the General Belgrano. ${ }^{\text {xxxiv }}$ Straightaway this tilted the probable development of events in the South Atlantic away from a diplomatic outcome, with which Ireland would have been comfortable, and towards a military one, which was much_łess parder to square with Ireland's commitment to neutrality. But the controversial manner in which the Argentine cruiser had been sunk, also stirred up comprehensible Irish sensitivities about British heavy-handedness. ${ }^{\text {xxxv }}$ The whole Irish party-political system after all was still one which bore the evident imprint of the divisions and controversies caused by Ireland's struggle for independence from Britain and the subsequent civil war. In the early 1980s moreover such historical sensibilities had been strongly revived by the ongoing Troubles in Northern Ireland. And in AprilMay 1982, Irish anxieties about the tactlessness and insensitivity of its larger neighbour were further accentuated by the Royal Navy's mishandling of an incident where a British submarine sank an Irish trawler, the Sharelga, 30 miles off Dublin Bay, but failed to surface or acknowledge the damage caused. ${ }^{\text {lxxxvi }}$ In such circumstances, it was not surprising that Haughey and Fianna Fáil were tempted to distance themselves from an overtly pro-British stance on the Falklands. ${ }^{\text {lxxxvii }}$ This was all the more so with a knife-edge by-election due in Dublin West. ${ }^{\text {lxxxviii }}$ A new Irish government statement on 4 May made it clear that Ireland would not be favourable to a renewal of EC sanctions 
and announced the country's intention to call for a new UN resolution on the South Atlantic which would insist on an immediate ceasefire. ${ }^{\text {lxxix }}$

The Italian and Irish positions, plus hints that other member states might also be reconsidering their support as the fighting intensified, caused significant concern in London. Pym, for instance, reported his fears about the possible non-renewal of sanctions to Cabinet colleagues on 6 May. ${ }^{\mathrm{xc}}$ To avoid this happening, UK ministers and diplomats stepped up their multilateral and bilateral lobbying within the Community. On 5 May, Pym sent all of his counterparts amongst the Ten a skilfully worded message, outlining the state of play diplomatically, explaining the circumstances in which the Belgrano had been sunk, and emphasising the importance of renewing the sanctions so as to maintain pressure on Argentina. ${ }^{x c i}$ A slightly different text was sent to Dublin, lamenting the 4 May statement but asking that Ireland allow the rest of the EC to press ahead with the renewal of sanctions even if the Irish themselves felt unable to follow suit. A precedent existed, it was pointed out, for a sanctions decision being taken even without total internal support, since Greece had refused to associate itself with the steps taken over Poland in 1981, but had allowed the others to impose sanctions nonetheless. ${ }^{x}$ ii The Foreign Secretary was then able to reiterate this message to his colleagues at the informal Council meeting at Villiers-le-Temple on 8-9 May. ${ }^{\text {xciii }}$ Thatcher meanwhile, wrote to her fellow members of the European Council, and followed this up with telephone calls to Haughey and Spadolini (although in fact she ended up speaking to Colombo). ${ }^{\text {xciv }}$ And Pym accepted with alacrity an offer by the US Secretary of State to lobby key European states on the UK's behalf. On May 13, the Foreign Secretary told Haig that Britain 'would be grateful for anything further he can do to encourage our EC partners to renew the embargo. The situation is on a knife-edge in a number of capitals. Although most would probably join a consensus if all others 
favor renewal, there is danger of a domino effect if a significant minority comes out against renewal. ${ }^{x c v}$ Haig then wrote to each of the foreign ministers of the Ten and also met with Colombo in Luxembourg. ${ }^{x c v i}$ The Americans, though, were clearly sceptical about the efficacy of British efforts or indeed of their own intervention. A 21 May memo to Haig, entitled 'The UK - Alone' predicted that the EC would fail to renew the sanctions when they expired the following week, and that Britain faced 'estrangement from its EC allies'. ${ }^{x c v i i}$

In the event, however, the EC support for Britain's position did not crumble. ${ }^{\text {xcviii }}$ After three hours of sometimes heated discussions amongst EC foreign ministers on the margins of the NATO ministerial meeting in Luxembourg on 18 May, the Ten were able to agree that seven of Britain's nine partners would renew the Community measures for a week, Denmark would use the interval to prepare national legislation to take the place of article 113 sanctions, and Italy and Ireland, while unable to renew the import ban, would maintain the arms embargo and take steps to ensure that no goods imported into their countries from Argentina found their way to other Community buyers. ${ }^{\text {xcix }}$ Seven days later, a Council meeting in Brussels agreed unanimously to extend the sanctions indefinitely 'until the situation permitted [their] removal', an outcome significantly better than the British had anticipated going into the talks. ${ }^{\mathrm{c}}$ Ireland and Italy were exempted once more, but again it was agreed that steps would be taken under article 225 of the Treaty of Rome to ensure that they were not used as intermediaries by companies elsewhere in the EC seeking to import from Argentina. The Belgian presidency also made a statement after the meeting strongly reaffirming EC solidarity with the UK. Pym may have exaggerated somewhat in speaking to the press of 'almost increased backing' in terms of the economic pressure 
applied, but EC had proved flexible enough to accommodate Italy and Ireland's special positions and yet still maintain a forceful economic embargo towards Argentina. ${ }^{\text {ci }}$

Neither the position of Italy nor Ireland, furthermore, justified the language of 'betrayal' bandied about in some parts of the British press or the Sun's call for a consumer boycott of Irish butter. ${ }^{\text {cii }}$ Indeed in many ways the debates within each country highlight how remarkable had been their original agreement to go along with EC sanctions. In the Italian case, after all, applying sanctions against a country with such close 'kith and kin' ties was analogous to the British imposing sanctions on Australia or New Zealand at the behest of a Community partner - something unlikely to be easily accepted. The Italians furthermore tried hard to ensure that their political support for Britain remained strong. The Italian ambassador in Buenos Aires was for instance instructed in mid-May, after the sanctions decision, to tell Argentina that its behaviour placed the country on 'the margins of the Western world.' ciii And it is also instructive to compare Italy's actions with those of Spain, the other West European country with deep blood and cultural links to Argentina, but one that was not yet a member of the EC. For in the Spanish case, public opinion appears very strongly to have been pro-Argentine rather than pro-British, and the government line, while rather more cautious and measured, was nevertheless a lot less supportive of Britain's actions than Italy. ${ }^{\text {civ }}$ Ireland too went initially much further than might have been expected for a country still wedded to foreign policy neutrality being asked strongly to back its former colonial overlord in a dispute that had strong colonial overtones. The extraordinary outburst of British indignation at Ireland's growing unease, which was not confined to the tabloids but crept into government too with at least one internal committee dubbing the Republic's post-4 May stance 'wicked or stupid', therefore probably says more about the heightened level of emotions in London and a recurrent 
British tendency to take Ireland for granted than it does about any deep streak of perfidy in Dublin. ${ }^{\mathrm{cv}}$ British annoyance about Ireland's failure to consult before acting in the $\mathrm{UN}$ is also less justified than might at first appear. ${ }^{\text {cvi }}$ Both the Irish actions that most angered the British, namely the 4 May call for a new Security Council resolution on the Falklands and then, in early June, the decision to vote in favour of the Spanish and Panamanian resolution calling for an immediate ceasefire - a step which obliged the UK to employ its veto - were actions in the Security Council. This matters because votes in the Security Council, in ther specifically excluded from the normal realm of EC coordination in New York largely at the insistence of the two EC member states who were permanent Security Council members, France and Britain!cvii

Overall then it would be reasonable to claim that the EC provided a surprising degree of support and backing for the UK during the Falklands dispute. The intensification of the conflict from early May onwards put severe pressure on the proUK consensus within the EC, but contrary to British and US fears, sanctions were renewed and the level of political support for the UK position remained strong. This outcome is particularly striking given the widespread assumption, especially in the literature about foreign policy coordination amongst EC/EU countries, that effective foreign policy unity was seldom if ever achieved prior to the 1990s and the introduction of a European Common Foreign and Security Policy (CFSP) by the 1992 Maastricht Treaty. ${ }^{\text {cviii }}$ Instead this article would suggest that Schmidt was rather closer to the truth when he had observed somewhat wearily to Thatcher in March 1982, a month before the Falklands crisis had begun, that 'the only value of the Economic Community at the moment lay in the political cooperation of Foreign Ministers - the rest was an empty shell.' ${ }^{\text {cix }}$ The Chancellor was exaggerating of course. Important elements of economic 
integration continued to function, albeit less well than many had hoped. ${ }^{\mathrm{cx}}$ But his words do act as a useful reminder that in the early 1980s, the most dysfunctional element of the integration process was the working of the core economic policies, whereas the process of enabling Europe to speak with a single voice on some foreign policy issues at least was regarded as something that functioned well. The largely successful coordination of European positions over the crisis in the South Atlantic would provide a further, powerful confirmation of this imbalance.

In terms of its ultimate impact on the Falklands War, this notable exercise in European cooperation and coordination probably mattered relatively little. The fate of the islands would in the end be decided by feat of arms, rather than diplomatic or economic pressure, and it was hence the United States, with the significant logistical and intelligence help that it was able to provide, which would emerge as the UK's most valuable ally. ${ }^{\text {cxi }}$ Of the European powers, only France and Germany were of any real significance in a military conflict in the South Atlantic, and even then they mattered most for what they did not do - namely provide further arms to Argentina - rather than for the trade sanctions that they imposed. Nevertheless, the psychological impact on Britain of being strongly politically supported by all of its major Western partners was highly significant, especially during the early phases of the conflict when the United States was seeking to mediate and was hence taking a much less clearly pro-British position. The messages of thanks and appreciation sent by Thatcher and Pym to their European counterparts as victory became clear were hence both sincere and deserved - even if the Prime Minister slightly spoiled matters by failing to include Belgium in the list of most supportive states, despite the valuable role played by the holders of the EC presidency and by Leo Tindemans, the foreign minister, in particular. .xii $^{\text {xin }}$ 


\section{The lack of a European Falklands factor}

What did not happen, by contrast, was any significant change in British attitudes towards the European Community. In the early stages of the crisis, it had been widely predicted, that the prompt manner in which the nine had rallied to Britain's side, would have a transformative effect on the way in which the UK regarded its European partners. Bullard, for instance, had told his colleagues on 9 April, after thanking them for their backing, that 'if the Falklands crisis had a happy end this could have a significant impact on attitudes to Europe in the UK.'cxiii Likewise the first of Pym's briefings on the crisis for EC ambassadors included the observation that 'the Community's action had been most helpful to perceptions of the Community in the UK. ' ${ }^{\text {'xiv }}$ It was an expectation played upon by British pro-Europeans, several of whom used questions in parliament, to encourage ministers to underline how supportive 'Europe' was being. Sir Anthony Meyer for example persuaded Pym to promise to place the written statements supporting Britain issued by all of the Community member states in the House of Commons library. ${ }^{\mathrm{cxv}}$ And it was a hope shared amongst Britain's partners also. As Taylor observed after one of his first meetings with Genscher about the Falklands, 'Though he did not say so, the Germans clearly hope that this prompt and substantial political action by the Community will have a beneficial effect on attitudes towards the Community in Britain. ${ }^{\text {'xvi }}$ And yet there is little evidence to suggest that any such transformation occurred. Indeed, the early drafts of the retrospective paper written up by the Foreign Office on 'The International Implications of the Falklands Crisis' were critical of the Community's role, comparing it unfavourably with both the US and the Commonwealth - although revealingly this triggered a wave of complaints from the department's European specialists. ${ }^{\text {cxvii }}$ Also indicative of the non-arrival of 
any 'Falklands Factor' in British attitudes towards the EC, is the way in which a 1983 article in International Affairs by Roy Jenkins designed to mark ten years of British membership, omitted EC support over the Falklands entirely from its list of benefits which the country had derived from the EC. ${ }^{\text {cxviii }}$ So why didn't either the British public or the British political elite display any real and lasting gratitude to the EC for the support given?

The first element of an answer to this question is probably the depth of the divide within British politics on the European question. Such pre-existing polarization on the issue meant that any individual's assessment of how helpful EC partners had been was almost entirely skewed by the observer's prior position on the question of Europe. This became very obvious in the Commons debate of 26 May, where MPs reacted to both the European renewal of sanctions on Argentina and the 1982 climax of the rows between Britain and its partners over agricultural spending and the UK's contribution to the EC budget. ${ }^{\text {cxix }}$ The line-up of participants was itself eloquent. Thus speaking in favour of the government motion, were, amongst others, Edward Heath, Roy Jenkins, Maurice Macmillan, Pym and Douglas Hurd; the opponents, by contrast, included Peter Shore, Eric Heffer, Douglas Jay, while frequent points of order were made by Teddy Taylor, Meyer, Nicholas Budgen and Tam Dalyell. But for the absence of Enoch Powell and Tony Benn, the debate could in other words have been one from the 1975 referendum campaign. And the substance of the comments made was as predictable as the roster of speakers. For Heath, Jenkins or Hurd, Community support and assistance had been vital; for Heffer, Jay or Shore, plus a handful of Eurosceptic Tory backbenchers, it was a worthless sham. With positions on each side of the debate so deeply entrenched, there was little scope for a dramatic transformation of the UK's attitude. 
A second contributory factor may well have been the genuine parting of the ways that occurred between Britain and its European allies over the aftermath of the crisis. Even before fighting was over, it had become very clear that whereas the UK government in general, and Thatcher in particular, felt that so great had been the British effort and sacrifice to recapture the islands that there was no short or even medium term possibility of resuming negotiations with Argentina about the question of sovereignty, virtually all the other members of the Community believed that a diplomatic dialogue with Buenos Aires had quickly to resume. This divergence of views was already evident during von Staden and Gutmann's visit to London in early June. ${ }^{\text {cxx }}$ It was at its clearest at a dinner that Bullard had with his fellow political directors on 14 June. ${ }^{\text {cxxi }}$ And it was highlighted once more by Colombo's letter to Pym written as soon as the Argentinian surrender had occurred. ${ }^{\text {cxxii }}$ This disagreement then fed through into the somewhat fractious discussions between Britain and its partners about how soon the different sanctions should be lifted. ${ }^{\text {cxxiii }}$ A crisis that had begun with the UK and the rest of the EC in impressive lockstep, ended by contrast with division all too apparent. The fact that US administration had moved in the opposite direction, becoming more supportive as the crisis progressed may also have cast the Community's stance in an unflattering light - although the Americans were as keen as Britain's European allies to see the UK resume talks with Argentina. ${ }^{\text {cxxiv }}$

A third factor that soured the mood between London and its fellow Community capitals was the way in which EC support for the UK over the Falklands became entangled with the parallel discussions over Britain's contribution to the EEC budget. The row over how much money the UK paid into the Community budget long predated the Falklands War and would endure for several years afterwards. ${ }^{\text {cxxv }}$ It was also an affair that was already heading for an ill-tempered showdown between Britain 
and its partners before the Argentinian invasion occurred. ${ }^{\text {cxxvi }}$ But at a time when the UK was publicly asking its fellow EC members to accept significant economic pain in the name of Community solidarity, it is hardly surprising that some began to feel that the British needed to suspend their tactic of blocking the annual setting of agricultural prices within the EC - a step of crucial importance for thousands of farmers across Europe - until a satisfactory deal had been done on the budget. Genscher advised as much when he met Pym in Brussels on April 20. ${ }^{\text {cxxvii }}$ Rather recklessly the British decided to press on. This then led to a climatic meeting of the Agricultural Council in Brussels on 18 May, when Peter Walker, the Minister of Agriculture's repeated attempts to invoke the Luxembourg Compromise in order to block the setting of agricultural prices were deemed invalid and overridden. ${ }^{\text {cxxviii }}$ The UK's bluff had been called. Sensibly both Britain and its partners realised that a major row was in nobody's interests, and London swallowed its defeat over agricultural pricing and accepted a year-long budgetary deal less advantageous than it had hoped for, while the Community renewed its sanctions on Argentina indefinitely. ${ }^{\text {cxxix }}$ But the sense of mutual trust and solidarity had received a further blow. ${ }^{\text {cxxx }}$

Even more important, in the longer term, were the effects of victory in the South Atlantic on the self-confidence and national self-belief of Thatcher and her supporters. Britain, it should be remembered, had turned to European Community membership because of a deep sense that its powers were declining and that it was no longer strong enough to act as a major international player alone. The Cabinet debates of 1967 which had preceded the Labour application to join had included, for instance, the blunt observation that 'joining the Community was essential if we were to avoid finding ourselves increasingly isolated and powerless in world affairs. ${ }^{\text {'xxxi }}$ The debate about British 'decline' that loomed so large in the discourse of both the 1960s and the 
1970s was inextricably bound up with the simultaneous turn to Europe. $\frac{\text { cxxxii }}{\text { As would }}$ become clear from the triumphal tone adopted by Thatcher in the aftermath of victory in Falklands, however, the Prime Minister was convinced that by winning in the South Atlantic she and her country had taken a major step towards breaking this spiral of decline. As she put to a crowd of the Tory faithful in a rally in Cheltenham in July 1982:

When we started out, there were the waverers and the fainthearts. The people who thought that Britain could no longer seize the initiative for herself. The people who thought we could no longer do the great things which we once did. Those who believed that our decline was irreversible - that we could never again be what we were. There were those who would not admit it — even perhaps some here today—people who would have strenuously denied the suggestion but - in their heart of hearts - they too had their secret fears that it was true: that Britain was no longer the nation that had built an Empire and ruled a quarter of the world. Well they were wrong. The lesson of the Falklands is that Britain has not changed and that this nation still has those sterling qualities which shine through our history. ${ }^{\text {cxxxiii }}$

In the medium term this change of mood was heavy with consequence for Conservative attitudes towards Europe. Victory in the South Atlantic did not transform the debate about Europe overnight, needless to say. The altered mood would need time to sink in, and it would need to be flanked by other Tory triumphs of the 1980 s, like the 1983 and 1987 election victories and the improvement in British economic performance, to fully have its effect. But the domestic 'Falklands factor' - or the manner in which military success fed through into Conservative self-confidence and domestic political dominance - strongly contradicted any deep sense of gratitude or 
recognition of the assistance which Britain had received from its European partners. Instead the outcome of the war should be seen as a first, but still significant step, towards the emergence of a radically different self-perception of Britain and of its place in the world. What space this transformation left for membership of an integrating Europe would be a question that would become central to British politics over the decades ahead.

\section{Article length: 10,946 words, including}

${ }^{\mathrm{i}}$ The author would like to thank the numerous friends and colleagues who have read and commented on the manuscript and, alongside the two anonymous reviewers, helped tighten up its arguments significantly. Sadly there wasn't the space to include all of the extra material they suggested.

ii The most detailed study of the war is Lawrence Freedman, The Official History of the Falklands Campaign. Vol. II. War and Diplomacy (Abingdon: Routledge, 2005). For the impact of the crisis on Thatcher and her government, see Charles Moore, Margaret Thatcher: The Authorized Biography: Volume One: Not for Turning (London: Allen Lane, 2013), 656-758; Dominic Sandbrook, Who Dares Wins: Britain, 1979-1982. (London: Penguin Books, 2019); Domenico Maria Bruni, The British Political Parties and the Falklands War (Basingstoke: Palgrave Macmillan, 2018).

iii Ronaldo Munck, 'The Democratic Decade: Argentina Since Malvinas', Bulletin of Latin American Research 11, no. 2 (1992): 205-16.

${ }^{\text {iv }}$ Louise Richardson, When Allies Differ: Anglo-American Relations during the Suez and Falklands Crises (Basingstoke: Macmillan, 1996); Anthony Parsons, 'The Falklands Crisis in the United Nations, 31 March-14 June 1982', International Affairs 59, no. 2 (1983): 169 78; Noel Dorr, A Small State at the Top Table: Memories of Ireland on the UN Security Council, 1981-82 (Dublin: Institute of Public Administration, 2011), $121 \mathrm{ff}$. 
${ }^{\mathrm{v}}$ There is a brief discussion of the episode in Kiran Klaus Patel, Project Europe: A History (Cambridge \& New York: Cambridge University Press, 2020), 74-76; its interconnection with the budgetary row is noted in Stephen Wall, The Official History of Britain and the European Community, Volume III, The Tiger Unleashed, 1975-1985 (Abingdon: Routledge, 2019), 221-33. The only detailed studies, compiled before archives opened, were Stelios Stavridis and Christopher Hill, eds., Domestic Sources of Foreign Policy: West European Reactions to the Falklands Conflict (Oxford: Berg, 1996); Georges Saunier, 'La Guerre des Malouines: réflexions sur la coopération politique européenne', in L'Union Européenne, acteur de la sécurité mondiale. The EC/EU: A World Security Actor?, ed. Gérard Bossuat and Anne Deighton (Paris: Soleb, 2007), 402-19.

vi The use of the term 'Falklands Factor' to describe the boost provided by the war to the popularity of both Thatcher and her party was already evident by the end of the conflict itself, as is shown by Robert Gray, 'The Falklands Factor', Marxism Today, July 1982, 8-12.

vii Archive of European Integration, Pittsburgh, http://aei.pitt.edu/5584/1/5584.pdf, 7.

${ }^{\text {viii }}$ UKNA, FCO7 4590, Carrington to UKREP, Tels. 276 \& 277, 2 Apr. 1982; Bullard to Fearn, 'Falkland Islands', 2 Apr. 1982; Brussels COREU, CPE/MUL ETR 1354, 'Iles Falkland', 2 Apr. 1982

${ }^{\text {ix }}$ Maria Gainar, Aux origines de la diplomatie europeenne: les neuf et la cooperation politique europeenne de 1973 a 1980 (Brussels: P.I.E. Peter Lang, 2012), 559.

${ }^{\mathrm{x}}$ Lisa L. Martin, 'Institutions and Cooperation: Sanctions during the Falkland Islands Conflict', International Security 16, no. 4 (1992): 154.

${ }^{\mathrm{xi}}$ Lorenzo Ferrari, Sometimes Speaking with a Single Voice: The European Community as an International Actor, 1969-1979, 2016, 184-88; Sara Tavani, 'The Détente Crisis and the Emergence of a Common European Foreign Policy: The "Common European Polish Policy"”, in Europe in a Globalising World: Global Challenges and European Responses in the 'Long' 1970s, ed. Claudia Hiepel (Baden-Baden: Nomos, 2014), 49-68. 
xii UKNA, PREM 19 614, Carrington to PM, 'Falkland Islands: Economic Measures', 5 Apr. 1982

xiii UKNA, FCO7 4590, Nicoll to FCO, tels. 1458 \& 1460, 9 Apr. 1982.

xiv The author is grateful to Morten Rasmussen for explaining the rationale of the Danish position. See also Henrik Larsen, 'A Mixed Reaction: Denmark', in Domestic Sources of Foreign Policy, ed. Stavridis and Hill, 98-113.

${ }^{\mathrm{xv}}$ Simon J Nuttall, European Political Co-Operation (Oxford: Clarendon Press, 1992); Eleonora Guasconi, Prove di politica estera. La cooperazione politica europea, l'Atto unico europeo e la fine della guerra fredda (Milan: Mondadori Università, 2020).

${ }^{x v i}$ On Italy, UKNA, FCO7 4590, Arculus to FCO, tel. no. 153, 7 Apr. 1982. For more detail Giulia Bentivoglio, 'Venti di crisi tra Roma e Londra? Il conflitto delle Falkland/Malvinas e le relazione Anglo-Italiane', Storia e Politica: Annali della Fondazione Ugo La Malfa 32 (2017): 199-218; Lorenzo Mechi and Andrea Chiampan, 'Des intérêts difficilement conciliables: l'Italie, l'Europe et la crise des Falkland (avril-juin 1982)', Guerres Mondiales et Conflits Contemporains, no. 245 (2012): 115-32; Domitilla Savignoni, 'The Internal Dissenter (i): Italy', in Domestic Sources of Foreign Policy, ed. Stavridis and Hill, 114-31. xvii UKNA, FCO7 4590, Nicoll to FCO, tels. 1458, 9 Apr. 1982

xviii UKNA, FCO7 4590, Nicoll to FCO, tel. 1464, 10 Apr. 1982; for the Italian agreement, see FCO7 4590, Arculus to FCO, tel. 159, 10 Apr. 1982

${ }^{x i x}$ UKNA, FCO7 4591, Nicoll to FCO, tel. 1481, 14 Apr.1982

${ }^{\mathrm{xx}}$ For the 9 April meeting, see esp. UKNA, FCO7 490, Bullard to FCO, tel. 77, 9 Apr. 1982.

${ }^{x x i}$ UKNA, FCO7 4590, Nicoll to FCO, tels. 1458 \& 1460, 9 Apr. 1982 \& FCO7 4591, Nicoll to FCO, tel. 1481, 14 Apr. 1982.

xxii UKNA, FCO7 4590, Nicoll to FCO, tels. 1410 \& 1412, 6 Apr. 1982; Pym to UKREP, tel. 292, 6 Apr. 1982.

xxiii UKNA, FCO7 4590, Cresswell to Hurd, 8 Apr. 1982

${ }^{\text {xxiv }}$ UKNA, PREM 19 615, Pym to Brussels, tel.72, 6 Apr. 1982. 
${ }^{x x v}$ Both Pym and Thatcher went out of their way to thank the Belgian presidency in these early stages, something that the Prime Minister was rather less good at doing later on. See e.g. UKNA, FCO7 4591, Pym to Rome, tel. 81, 11 Apr. 1982.

${ }^{x x v i}$ UKNA, FCO33 5681, Taylor to FCO, tel. 307, 7 Apr. 1982

xxvii UKNA, FCO7 4591, FCO to Athens, tel. 91, 13 Apr. 1982.

xxviii Foreign Relations of the United States 1981-1988 (henceforward FRUS 1981-88), volume

XIII, 'Conflict in the South Atlantic, 1981-1984', 206

${ }^{\text {xxix }}$ Freedman, The Official History of the Falklands Campaign. Vol. II, 101-2._Certain portions of the US administration, notably the Department of Defense, adopted a pro-British line from the outset, but this was initially overshadowed by the more neutral position adopted by Reagan and Haig.

${ }^{\mathrm{xxx}}$ Dorr, A Small State at the Top Table, 135.

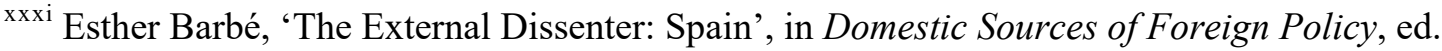
Stavridis and Hill, 163.

xxxii UKNA, FCO33 5573, Thatcher to Mitterrand, 4 Apr. 1982.

xxxiii UKNA, FCO7 4591, Graham to Gillmore, 13 Apr. 1982.

${ }^{\text {xxxiv }}$ UKNA, FCO33 5681, Taylor to FCO, tel.295, 4 Apr. 1982

${ }^{\text {xxxv }}$ UKNA, FCO7 4590, Appendix K, ‘Argentina: Economic Vulnerability’, undated but clearly prepared in early April 1982.

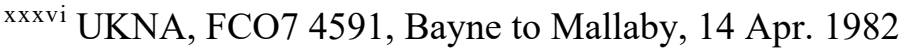

xxxvii US arms sales to Argentina were substantially impeded by the 1977 Humphrey-Kennedy amendment. FRUS 1981-88, vol. XIII, 86.

xxxviii FRUS 1981-88, volume XIII, 269-270

${ }^{\text {xxix }}$ https://api.parliament.uk/historic-hansard/commons/1982/apr/14/falkland-islands, column 1148.

${ }^{\mathrm{xl}}$ Italy too should have been regarded as one of the big states, but as so often the British thought otherwise. On this tendency, see N. Piers Ludlow, 'In Search of Balance: Italy, Britain and 
the "dream" of Another European Axis', in L'Italia nella construzione Europea. Un bilancio storico (1957-2007), ed. Piero Craveri and Antonio Varsori (Milan: FrancoAngeli, 2009).

${ }^{x l i}$ See e.g., UKNA, PREM 19 1225, 'Post-Stuttgart Negotiations: The Budget Inequity. Line to take with Chancellor Kohl on 8-9 November', undated but clearly early Nov.1983.

${ }^{x}$ lii Most recently in Zaire in 1978 and Chad (1978-80). For details see https://histoirecoloniale.net/1960-2010-50-ans-d-interventions.html. I am grateful to Frédéric Bozo for confirming my hunch on this.

xliii Roland Dumas, Affaires Étrangères. 1981-1988, vol. 1 (Paris: Fayard, 2007), 53-70.

${ }^{\text {xliv }}$ See also Georges Saunier, 'La diplomatie mitterrandienne face à la guerre des Malouines : l'Europe ou l'Amérique latine ?', Le Genre humain N 58, no. 1 (23 Nov. 2017): 69-86. ${ }^{x l v}$ UKNA, FCO33 5573, 'Telephone conversation between Prime Minister and President Mitterrand, Saturday, 3 April 1982'. ${ }^{x l v i}$ UKNA, FCO33 5573, Thatcher to Mitterrand, 4 Apr. 1982.

${ }^{x l v i i}$ Compare and contrast their two conversations on 17 May. Margaret Thatcher Foundation

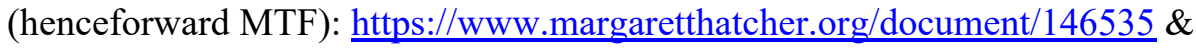
https://www.margaretthatcher.org/document/146536 xlviii UKNA, FCO33 5573, Thatcher to Mitterrand, 26 Apr. 1982.

${ }^{x l i x}$ UKNA, FCO33 5573, Britdefat Paris to MOD, GRS 180, 7 Apr. 1982.

${ }^{1}$ UKNA, FCO33 5573, Britdefat Paris to MOD, GRS 90, 11 May 1982

${ }^{\text {li } U K N A, ~ F C O 33 ~ 5574, ~ W e s t o n ~ t o ~ S t e w a r t, ~} 25$ May 1982.

${ }^{\text {lii }}$ For the end of a long-running saga, see MTF: https://www.margaretthatcher.org/document/124234

liii John Nott, Here Today, Gone Tomorrow: Recollections of an Errant Politician (London: Politico's, 2003), 305. On Dassault's role, see https://www.bbc.co.uk/news/magazine$\underline{17256975}$

${ }^{\text {liv }}$ Mathias Haeussler, Helmut Schmidt and British-German Relations: A European Misunderstanding,(Cambridge: Cambridge University Press, 2019), 149-207. 
${ }^{\text {lv }}$ UKNA, FCO33, 5682, Taylor dispatch, 'German attitudes to the Falklands Crisis', WRG 021/9, 9 July 1982

${ }^{\text {lvi }}$ UKNA, FCO33 5681, Taylor to FCO, tel. 310, 8 Apr. 1982. My father's recollections from meeting several senior German officials in Bonn during this period confirm German bewilderment at so much being risked for so little.

lvii See for example Genscher's conversation with Spadolini. Akten zur Auswärtigenpolitik der Bundesrepublik Deutschland 1982 (AAPD 1982) (Munich: Oldenbourg Verlag, 2013), document 143,724 .

lviii See e.g., UKNA, FCO33 5681, Taylor to FCO, tel. 304, 6 Apr. 1982.

${ }^{\text {lix }}$ UKNA, FCO33 5681, Harding to FCO, tel. 71, 6 Apr. 1982.

${ }^{1 x}$ UKNA, FCO33 5681, Taylor to FCO, tel. 320, 13 Apr. 1982.

${ }^{\text {lxi }} A A P D$ 1982, document 145. For a British summary of discussions at Villiers-le-Temple, UKNA, FCO 4593, Pym to UKREP, tel. 413, 10 May 1982.

Ixii The issue was first mentioned in UKNA, FCO33 5681, Taylor to FCO, tel. 306, 7 Apr. 1982. Ixiii The twists and turns of the plot over the summer months can be followed in UKNA, FCO33 5684.

lxiv UKNA, FCO7 4590, FCO to UKREP, tel. 287, 5 Apr. 1982.

${ }^{1 x v}$ UKNA, FCO33 5681, Taylor to FCO, tel. 338, 16 Apr. 1982, Taylor to FCO, tel. 353, 21 Apr. 1982, Pym to Bonn, tel. 156, 22 Apr. 1982.

${ }^{\text {Ixvi }}$ See the handwritten minute in the margin of FCO33 5681, Taylor to FCO, tel. 367, 22 Apr. 1982. The extension of the meetings is clear from Pym to Bonn, tel. 228, 14 May 1982 ${ }^{\text {Ixvii }}$ UKNA, FCO33 5574, Pym to Paris, unnumbered telegram, 2 June 1982. ${ }^{1 x v i i i}$ For records of both meetings, see $A A P D$ 1982, documents $137 \& 158$. A British summary of the Northolt bilateral is in UKNA, FCO33 5681, Pym to Bonn, tel. 202, 6 May 1982. ${ }^{1 x i x}$ UKNA, FCO33 5681, Cole to Holmes, 'Falkland Islands: Conversation with Chancellor Schmidt', 7 Apr. 1982; ibid., Cole to Fall, 'Chancellor Schmidt', 29 Apr. 1982; FCO33 5573, 'Telephone conversation between Prime Minister and President Mitterrand, Saturday, 
3 April 1982'. For the German records: AAPD 1982, documents $110 \& 130$. The

Mitterrand-Thatcher talk is at: https://www.margaretthatcher.org/document/146536. For the Schmidt-Thatcher bilateral, UKNA, FCO33 5682, 'Record of a meeting between the Prime Minister and Chancellor Schmidt at the Grand Trianon, Versailles, on Saturday $5^{\text {th }}$ of June, 1982 at 18.40 hours.'

${ }^{1 x x}$ Larsen, ‘A Mixed Reaction: Denmark'.

${ }^{1 x x i}$ UKNA, FCO7 4593, 'European Political Cooperation, Political Committee, Brussels, 15

May 1982'. For the way in such difficulties played out in COREPER, ibid., Butler to FCO, tel. 1987, 18 May 1982.

${ }^{\text {lxxii }} A A P D$ 1982, document 143, here 723-4.

1xxiii The most detailed British analysis of why the Italians would ultimately prove unable to renew EC sanctions was provided in UKNA, FCO7 4593, Simpson-Orlebar to Goodison, 25 May 1982.

lxxiv Savignoni, 'The Internal Dissenter (i): Italy', 118. Only the US had higher levels of investment in Argentina.

${ }^{\text {lxxv }}$ UKNA, FCO7 4593, Simpson-Orlebar to FCO, tel. 251, 12 May 1982. See also Bentivoglio, 'Venti di crisi tra Roma e Londra?, 206-7.

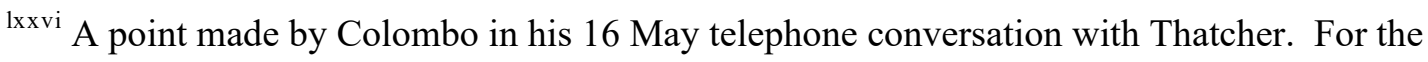
transcript see, MTF: $\underline{\text { https://www.margaretthatcher.org/document/150460 }}$ lxxvii Mechi and Chiampan, 'Des intérêts difficilement conciliables', 122 \& 124. Ixxviii UKNA, FCO7 4593, Simpson-Orlebar to Goodison, 25 May 1982.

${ }^{\text {Ixxix }}$ Bentivoglio, 'Venti di crisi tra Roma e Londra?, 207-8.

${ }^{1 x x x}$ The most recent contribution on Ireland's position is Stephen Kelly, 'An Opportunistic Anglophobe: Charles J. Haughey, the Irish Government and the Falklands War, 1982', Contemporary British History 30, no. 4 (1 October 2016): 522-41. Older but still very useful is Norman MacQueen, 'The Expedience of Tradition: Ireland, International Organization and the Falklands Crisis', Political Studies 33, no. 1 (1985): 38-55. 


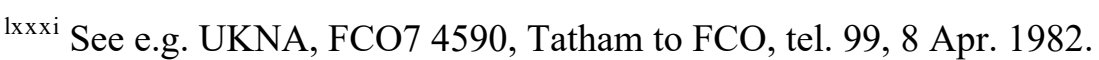

Ixxxii Joe Joyce and Peter Murtagh, The Boss: Charles J. Haughey in Government (Dublin:

Poolbeg Press, 1983), 157; Dorr, A Small State at the Top Table, 136-42; Ben Tonra,

'Internal Dissenter (II): Ireland', in Domestic Sources of Foreign Policy, ed. Stavridis and

Hill, 139-40.

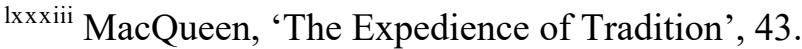

${ }^{\text {lxxiv }}$ See Freedman, The Official History of the Falklands Campaign. Vol. II. 284-93 \& 321-31.

${ }^{\text {lxxxv }}$ See MTF: https://www.margaretthatcher.org/document/137099.

lxxxvi Joyce and Murtagh, The Boss, 159-60.

Ixxxvii Haughey's personal centrality to the Irish stance is a common theme in both the literature and British diplomatic reporting. See e.g. UKNA, FCO7 4592, Figg to FCO, tel. 130, 5 May 1982 \& Kelly, 'An Opportunistic Anglophobe'.

lxxxviii Joyce and Murtagh, The Boss, 169-75.

lxxxix The text of the Irish statement is in UKNA, FCO7 4592, Figg to FCO, tel. 124, 4 May

1982. Tel. 125, details the British Ambassador's talk with Haughey immediately after the Irish statement.

${ }^{x c}$ UKNA, CAB 128/73/24, CC(82) 24, Cabinet Conclusions, 6 May 1982.

${ }^{\text {xci }}$ UKNA, FCO7 4592, Pym to Paris, tel. 216, 6 May 1982.

xcii Ibid.

${ }^{x c i i i}$ UKNA, FCO7 4593, Pym to UKREP, tel. 413, 10 May 1982. See also AAPD 1982, document 145 .

${ }^{x c i v}$ The letter is referred to in UKNA, FCO7 4593, Figg to FCO, tel. 142, 11 May 1982 \& ibid. Arculus to FCO, tel. 251, 12 May 1982. For the conversation with Colombo, see ibid. Jay note, 16 May 1982 \& that with Haughey: ibid., Whitmore to Richards, 'Ireland and Sanctions against Argentina’, 17 May 1982.

${ }^{\mathrm{xcv}}$ FRUS 1981-88, vol. XIII, 541-2. 
${ }^{\mathrm{xcvi}}$ For the text of the letter, see MTF https://www.margaretthatcher.org/document/124029; for the meeting with Colombo: FRUS 1981-88, vol. XIII, 562-4.

${ }^{\text {xcvii }}$ FRUS 1981-88, vol. XIII, 509-601.

xcviii Contrary to the line taken by Saunier, 'La Guerre des Malouines', 413-19.

${ }^{x c i x}$ UKNA, FCO7 4593, Pym to Luxembourg, tel. 56, 18 May 1982. Pym acknowledged to the Cabinet on 20 May, that the short interval of renewal was less damaging than made out in the press and that support for Britain remained strong. CAB 128/73/28, CC(82) 28, 20 May 1982.

${ }^{\mathrm{c}}$ UCNA, FCO7 4593, Butler to FCO, tel. 2063, 24 May 1982. For a sense of British uncertainty about how far their partners would go, see the briefs prepared for the Council/EPC meeting: ibid., 'Meeting of EC Foreign Ministers, Brussels, 24 May 1982'.

${ }^{\text {ci }}$ UKNA, FCO7 4593, Butler to FCO, tel. 2065, 24 May 1982.

${ }^{\text {cii }}$ Mechi and Chiampan, 'Des intérêts difficilement conciliables', 125; Kelly, 'An Opportunistic Anglophobe', 532.

ciii UKNA, FCO7 4593, Bullard note, 'Falklands: Italian views', 20 May 1982.

${ }^{\text {civ }}$ The comparison is not totally fair given the Gibraltar factor. But the difference between the Spanish and Italian behaviours is still revealing. Barbé, 'The External Dissenter: Spain'. See also 'The Rock that could block Spain's road to Europe', The Economist, 26 June 1982.

${ }^{c v}$ The phrase was used in the report of the Information Group on the Falklands, chaired by Bernard Ingham, on 5 May. See MTF: https://www.margaretthatcher.org/document/127508

${ }^{\text {cvi }}$ See e.g. UKNA, FCO7 4592, Pym to Brussels, tel. 98, 4 May 1982.

${ }^{\text {cvii }}$ Rosemary Foot, 'The European Community's Voting Behaviour at the United Nations General Assembly', JCMS: Journal of Common Market Studies 17, no. 4 (1979): 351-52; Lorenzo Ferrari, 'How the European Community Entered the United Nations, 1969-1976, and What It Meant for European Political Integration', Diplomacy \& Statecraft 29, no. 2 (3 April 2018): 246-48. 


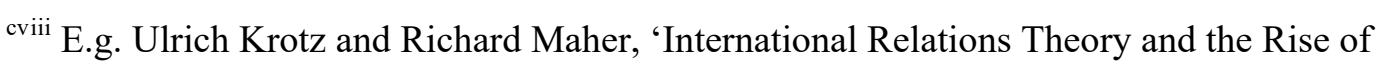
European Foreign and Security Policy', World Politics 63, no. 3 (July 2011): 548-79.

${ }^{\text {cix }}$ See MTF: https://www.margaretthatcher.org/document/137885

${ }^{\mathrm{cx}}$ Mark Gilbert, European Integration: A Political History, Second Edition (Lanham: Rowman \& Littlefield, 2020).

${ }^{\mathrm{cxi}}$ Freedman, The Official History of the Falklands Campaign. Vol. II, 379-85.

cxii The clearest message of thanks was Pym's circular to his EC counterparts of 9 June. UKNA, FCO7 4594, Pym to Brussels, tel. 142, 9 June 1982. Significantly the Irish were not sentemithe most generous portion of the text an example of Thatcher's gratitude, see her comments to Schmidt at Versailles. FCO33 5682, 'Record of a meeting between the Prime Minister and Chancellor Schmidt at the Grand Trianon, Versailles, on Saturday $5^{\text {th }}$ of June, 1982 at 18.40 hours.' For Thatcher's omission of the Belgians and subsequent FCO appeals that this be rectified, MTF:

https://www.margaretthatcher.org/document/104952 \&

https://www.margaretthatcher.org/document/135614

cxiii UKNA, FCO7 4590, Bullard to FCO, tel. 77, 9 Apr. 1982.

cxiv UKNA, FCO7 4591, Pym to Brussels, Tel. 302, 13 Apr. 1982.

${ }^{c x v}$ https://api.parliament.uk/historic-hansard/written-answers/1982/apr/19/falkland-islands-2

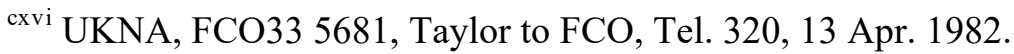

cxvii UKNA, FCO7 4954, Wood to Mallaby, 24 June 1982.

cxviii Roy Jenkins, 'Britain and Europe: Ten Years of Community Membership', International Affairs (Royal Institute of International Affairs 1944-) 59, no. 2 (1983): 147-53.

${ }^{\text {cxix }}$ https://api.parliament.uk/historic-hansard/commons/1982/may/26/european-community

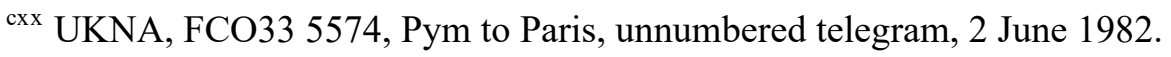

cxxi UKNA, FCO7 4594, Bullard note 'Argentina Economic sanctions', 15 June 1982.

cxxii UKNA, FCO7 4594, Fontana Giusti to Pym, 16 June 1982.

cxxiii UKNA, FCO7 4594, Pym to Brussels, tel. 158, 18 June 1982. 
${ }^{\text {cxxiv }}$ Nicholas Henderson, Mandarin: The Diaries of an Ambassador, 1969-1982 (London:

Weidenfeld and Nicolson, 1994), 465-75.

${ }^{\mathrm{cxxv}}$ Wall, The Official History of Britain and the European Community, Volume III, 136-288.

${ }^{\text {cxxvi }}$ Schmidt and Mitterrand's mounting frustration was evident in their 31 March bilateral. AAPD 1982, document 99.

${ }^{\text {cxxvii }}$ AAPD 1982, document 125, footnote 6.

cxxviii UKNA, CAB 128/73/28, CC(82)28, 20 May 1982.

${ }^{\text {cxxix }}$ Michael Butler, Europe: More than a Continent (London: Heinemann, 1986), 100-101.

${ }^{\text {cxxx }}$ UKNA, CAB 128/73/29, CC(82)29, 25 May 1982.

cxxxi UKNA, CAB 128, CC (67) 26, 30 Apr. 1967

cxxxii The debate about 'decline' features prominently in the most recent analysis of the 1975

referendum: Lindsay Aqui, The First Referendum: Reassessing Britain's entry to Europe,

1973-75 (Manchester: Manchester University Press, 2020), 239-43

cxxxiii MTF: https://www.margaretthatcher.org/document/104989 